\title{
PENGEMBANGAN MEDIA PERMAINAN SAINS FEED THE ZOO ANIMALS BERBANTU FLASH CARD UNTUK MEMFASILITASI KEMAMPUAN MENGENAL HURUF
}

\author{
Ghias Isqi Arifani ${ }^{1}$, Edi Hendri Mulyana ${ }^{2}$, Sumardi $^{3}$ \\ ${ }^{1}$ Program Studi PGPAUD UPI Kampus Tasikmalaya \\ ${ }^{2}$ Program Studi PGPAUD UPI Kampus Tasikmalaya \\ ${ }^{3}$ Program Studi PGPAUD UPI Kampus Tasikmalaya \\ Email : ghiasisqi@gmail.com
}

(Received: Mei 2020; Accepted: Mei 2020; Published: Juni 2020)

\begin{abstract}
The research problem was obtained through a preliminary study in the Al-Hamid Kindergarten in Tasikmalaya City, namely the difficulty of the teacher in making and developing learning media that is suitable to the needs, especially the media to recognize letters. The methode used is expansing methode type EDR from Mckenney and Reeves as generic model. Streps to do is : 1) analysis and exploration step, design and construction step, evalution and reflection step. Product constructed is learning and playing science media feed the zoo animals aided flash card. The media is specially designed for introducing letters variated with science consept. This research can only done two steps that is analysis and exploration then design and construction. The, evalution and reflection step can't be held, remembering there's trial and error processes due to thus Covid-19 pandemic (Coronavirus Disease 2019). Based on the results of the validation by a team of experts consisting of material experts, instructional media and pedagogics, the science game media feeds the zoo animals assisted with flash cards for further feasible use in learning in PAUD, as an alternative use of learning media that can facilitate aspects of child development only language development in particular is recognizing letters.
\end{abstract}

Keywords: Early Childhood; Letter Recognition Ability; Media Science Games Feed The Zoo Animals Aided Flash Cards.

\begin{abstract}
ABSTRAK
Permasalahan penelitian didapat melalui studi pendahuluan di TK Al-Hamid Kota Tasikmalaya yaitu kesulitan guru dalam membuat dan mengembangkan media pembelajaran yang sesuai dengan kebutuhan khususnya media untuk mengenal huruf. Metode yang digunakan yaitu metode pengembangan jenis EDR (Educational Design Research) dengan model Generik dari McKenney \& Reeves. Tahapan-tahapan yang dilakukan yaitu 1) tahap analysis and exploration 2) tahap design and construction; 3) tahap evalution and reflection. Produk yang dihasilkan berupa media permainan sains feed the zoo animals berbantu flash card. Media permainan tersebut dirancang secara khusus untuk mengenalkan huruf yang divariasikan melalui penanaman konsep sains. Penelitian ini hanya dapat melaksanakan dua tahap yaitu tahap analisis dan eksplorasi serta desain dan konstruksi. Tahap evaluasi dan refleksi tidak dapat dilakukan, mengingat tidak akan dilakukan uji coba produk, karena adannya pandemi covid-19 (Coronavirus Disease 2019). Berdasarkan hasil validasi oleh tim ahli yang terdiri dari ahli materi, media pembelajaran serta pedagogik, media permainan sains feed the zoo animals berbantu flash card untuk selanjutnya layak digunakan dalam pembelajaran di PAUD, sebagai salah satu alternatif penggunaan media pembelajaran yang dapat memfasilitasi aspek perkembangan anak salah satunya perkembangan bahasa khususnya mengenal huruf.
\end{abstract}

Kata Kunci: Anak Usia Dini; Mengenal Huruf; Media Permainan Sains Feed The Zoo Animals Berbantu Flash Card. 


\section{PENDAHULUAN}

Usia dini sering disebut dengan masa golden age dimana pada masa ini sangat penting untuk mengoptimalkan seluruh aspek perkembangan anak. Untuk itu memberikan pendidikan dan pembelajaran yang tepat sesuai dengan kebutuhan dan tingkat perkembangan anak pada usia tersebut sangatlah penting.

Proses belajar bagi anak baik yang dilakukan di sekolah maupaun di rumah erat kaitannya dengan kegiatan bermain. Mereka dapat menghabiskan sebagian waktunya untuk bermain dan mengeksplor kemampuan dirinya. Sebagaimana dikemukakan Bodrova dan Leong (dalam Tedjasaputra, 2001) dalam bermain, anak dapat menciptakan scaffolding secara mandiri baik dalam kontrol diri, penggunaan bahasa, daya ingat, dan kerja sama dengan teman bermain. Pendapat tersebut mengisyaratkan bahwa selain memerlukan bantuan dari pihak lain diluar dirinya dalam hal bermain, masingmasing anak memiliki kemampuan yang bersifat mandiri secara tersendiri. Melalui kegiatan bermain akan terlihat potensi serta kemampuan yang dimiliki oleh anak. Selain itu bermain merupakan salah satu bentuk ransangan atau stimulus yang dapat megembangkan pengetahuan serta keterampilannya. Karena dengan bermain anak memiliki kesempatan untuk bereksplorasi, mengekspresikan diri dan prasaan serta belajar secara menyenangkan.

Salah satu kemampuan anak yang sedang berkembang yaitu kemampuan berbahasa. Kemampuan berbahasa merupakan hal yang sangat penting dalam proses belajar bagi anak baik di lingkungan sekolah, keluarga dan masyarakat. Untuk itu sangat penting dilakukan stimulus agar kemampuan berbahasa anak dapat berkembang secara optimal. Kemampuan berbahasa merupakan kemampuan seseorang untuk menyampaikan ide atau fikirannya dengan menggunakan kalimat yang bermakna sehingga anak akan dengan mudah menyampaikan segala kebutuhan dirinya (Desmita, 2017; Santrock, 2007). Mengenalkan huruf merupakan salah satu langkah awal yang dapat dilakukan untuk mengoptimalkan kemampuan bahasa anak. Pentingnya anak dalam mengenal serta memahami huruf dikarenakan dalam kehidupannya sehari-hari anak akan banyak menemukan hal-hal yang berhubungan dengan huruf.

Kemampuan berbahasa anak dapat dikembangkan melalui pembelajaran sains. Hal tersebut sejalan dengan pendapat Worms, Shadow, dan Whirlpools (dalam jurnal Mirawati dan Nugraha, 2017, hlm.4) manfaat pembelajaran sains bagi anak yaitu dapat mengembangkan kemampuan sensor, fisik, intelektual, emosional, spiritual, dan sosial serta mengembangkan kemampuan berbahasa melalui penambahan kosakata ketika anak melakukan kegiatan menanya dan menjawab pertanyaan. Selain itu pembelajaran sains juga memiliki manfaat lain diantaranya dapat menumbuhkan rasa percaya diri pada anak, memberi pengalaman penting dan memberi kesempatan kepada anak untuk bereksplorasi. Mengingat pelaksanaan pembelajaran bagi anak usia dini tidak akan terlepas dari aktivitas bermain. Untuk itu pembelajaran sains akan lebih optimal apabila dilakukan melalui sebuah permainan.

Dalam sebuah permainan terdapat alat yang berfungsi sebagai sarana untuk menyampaikan informasi. Alat permainan memiliki arti semua alat bermain yang digunakan oleh anak untuk memenuhi naluri bermainnya dan memiliki berbagai macam sifat seperti bongkar pasang, mengelompokan, memadukan, mencari padanannya, merangkai, membentuk, mengetok, menyempurnakan suatu desain, atau menyusun sesuai bentuk utuhnya (Sudono, 2010, hlm. 7). Pada dasarnya guru dapat membuat sendiri media yang berfungsi sebagai alat permainan yang penggunaannya dapat mengoptimalkan penyampaian pesan pembelajaran. Rasyid dan Rohani (2018, hlm. 93) menjelaskan media sebagai suatu alat atau sarana sebagai perantara untuk menyampaikan bahan pelajaran dari guru kepada anak didik. Kutipan diatas mengisyaratkan perlunya penggunaan media sebagai penyalur pesan pembelajaran, sehingga seluruh informasi yang disampaikan guru dapat diterima anak dengan baik. Diharapkan terjadi perubahan berupa kemampuan dalam hal pengetahuan, sikap serta keterampilan anak. Selama ini disekolah-sekolah pada umunya ketersediaan media pembelajaran yang dapat memfasilitasi kemampuan mengenal huruf masih minim, termasuk di sekolah yang menjadi tempat penelitian. Media yang tersedia di 
sekolah tersebut baik media by utilization maupun media by design, kebanyakan hanya memfasilitasi perkembangan kognitif, fisik motorik, dan seni. Media by utilization adalah media yang sudah banyak terdapat dipasaran sedangkan media by design adalah media yang dirancang atau dipersiapkan secara khusus untuk kebutuhan pembelajaran (Zaman, B dan Eliyawati.C, 2010).

Hasil dari kegiatan wawancara pada studi pendahuluan dilapangan di TK Al-Hamid Kota Tasikmalaya, secara umum menunjukan masih kurangnya penggunaan media pembelajaran khususnya dalam bentuk media permainan yang bersifat variatif. Selama ini guru memanfaatkan media pembelajaran yang telah tersedia disekolah namun penggunaan media pembelajaran tersebut kurang dapat memfasilitasi seluruh aspek perkembangan anak, khususnya dalam aspek bahasa yakni mengenal huruf. Dalam mengenalkan huruf kepada anak, guru menggunakan media berupa kartu huruf serta menugaskan anak untuk mengisi LKA (lembar kerja anak). Selain itu berkaitan dengan pembelajaran sains, guru merasa kesulitan dalam mengembangkan media yang dapat digunakan dalam proses pembelajaran. Selama ini kegiatan sains yang dilakukan yaitu dengan mengajak anak mengamati lingkungan sekitar sekolah dan sesekali melakukan eksperimen sederhana dengan menggunakan alat dan bahan seadanya. Kurangnya ketersediaan media pembelajaran salah satunya dapat disebabkan oleh belum optimalnya upaya guru dalam membuat atau merancang media pembelajaran yang diperlukan dan sesuai dengan kebutuhan, melalui pemanfaatan bahan-bahan yang sudah tersedia.

Hasnida (2014, hlm. 24) media sering diidentikkan dengan berbagai jenis peralatan atau sarana untuk menyajikan pesan. Jadi media merupakan alat atau sarana yang dapat membantu guru dalam menyampaikan informasi atau pesan pembelajaran kepada anak, agar informasi atau pesan pembelajaran dapat diterima anak secara lebih optimal.

Suyadi (2015:183) mengemukakan permainan suatu yang menyenangkan, suka rela, penuh arti, dan aktivitas secara spontan. Permainan sering juga dianggap kreatif, menyertakan pemecahan masalah, belajar keterampilan sosial baru, bahasa baru dan keterampilan fisik yang baru. Menambahkan pendapat diatas Suminar (2019:93) menyebut permainan sebagai aktivitas bermain yang didalamnya megandung unsur kompetitif dan didalamnya terdapat serangkaian aturan dalam memainkannya. Sedangkan Asmarita (2019:12) permainan sains adalah proses atau cara untuk memahami dan mencari tahu serta menemukan jawaban tentang kenyataan yang ada disekitar melalui pengamatan, penyelidikan, dan percobaan yang dilakukan dengan menyenangkan dan menarik melalui kegiatan bermain. Berdasarkan uraian diatas dapat disimpulkan media permainan sains adalah alat atau sarana yang dapat digunakan untuk menyampaikan pesan pembelajaran, dikemas melalui sebuah permainan sehingga mengandung unsur kompetitif dan aturan tertentu serta dilakukan melalui pengamatan, penyelidikan dan percobaan secara menyenangkan.

Moomaw (2013) The science content in this center involves life science. The game helps children realize that not all animals eat the same type of food. It also builds vocabulary for children who have had little experience visiting or reading about zoo animals. Konten sains dalam pembahasan ini melibatkan sains kehidupan. Permainan ini membantu anak menyadari bahwa tidak semua hewan memakan jenis makanan yang sama. Permainan ini juga membantu menambah kosa kata anak yang baru memiliki sedikit pengalaman mengunjungi kebun binatang atau membaca buku mengenai kebun binatang.

Penggunaan permainan sains feed the zoo animals divariasikan dengan flash card. Aba (2019:172) Flashcards is a set of picture cards which are equipped with a word. It is introduced by Glenn Doman, a brain surgery from Philadelphia, Pennsylvania. The pictures on the cards can be classified into animal, fruits, clothes, color, shapes, and numbers. The contents of the flashcards can be modified according to the level of students, whether they are basic, intermediate, or advanced. Flash card adalah serangkaian kartu bergambar yang disimbokan dengan sebuah huruf awal. Flash card diperkenalkan oleh Glenn Doman, seorang ahli bedah otak dari 
Philadelphia, Pennsylvania. Gambar dalam kartu dapat dikelompokan menjadi hewan, buahbuahan, pakaian, warna, bentuk dan angka. Isi dari flash card dapat disesuaikan dengan tingkatan atau usia anak, dasar, menengah atau tinggi.

Berdasarkan uraian diatas dapat disimpulkan media permainan sains feed the zoo animals berbantu flash card adalah alat atau sarana yang dirancang khusus untuk memfasilitasi kemampuan mengenal huruf dan divariasikan dengan penanaman konsep sains, dikemas melalui sebuah permainan yang menggandung aturan-aturan tertentu seta dilakukan melalui pengamatan dan percobaan.

Berdasarkan paparan diatas peneliti melakukan pengembangan media permainan sains feed the zoo animals berbantu flash card untuk memfasilitasi kemampuan mengenal huruf anak usia dini 5 s.d. 6 tahun. Diharapkan produk yang dikembangkan dapat menjadi salah satu alternatif pemecahan masalah dari kurangnya ketersediaan media pembelajaran, khususnya media yang dapat digunakan dalam mengenalkan huruf.

Tujuan artikel ini yaitu : 1) Mendeskripsikan dasar kebutuhan pengembangan media permainan sains feed the zoo animals berbantu flash card untuk memfasilitasi kemampuan mengenal huruf anak usia dini 5 s.d. 6 tahun; 2) Mendeskripsikan rancangan desain pengembangan media permainan sains feed the zoo animals berbantu flash card untuk memfasilitasi kemampuan mengenal huruf anak usia dini 5 s.d. 6 tahun.

\section{TINJAUAN PUSTAKA}

\section{Media Permainan}

Media yaitu "alat atau sarana sebagai perantara untuk menyampaikan bahan pelajaran dari guru kepada anak didik." Rasyid dan Rohani (2018, hlm. 93). Satrianawati (2018, hlm 8) media "merupakan sesuatu yang bersifat menyalurkan pesan dan dapat merangsang pikiran dan prasaan bagi penggunanya." Dari uraian diatas dapat disimpulkan media sebagai peralatan atau sarana yang dapat digunakan oleh guru dalam menyalurkan isi pesan pembelajaran kepada siswa. Adapun manfaat media menurut Kemp \& Dayton (dalam Susilana \& Riyana, 2018, hlm. 9) sebagai berikut: a. Menyampaian pesan pembelajaran dapat lebih standar.

b. Pembelajaran dapat lebih menarik.

c. Pembelajaran menjadi lebih interaktif dengan menerapkan teori belajar.

d. Waktu pelaksanaan pembelajaran dapat diperpendek.

e. Kualtas pembelajaran dapat ditingkatkan.

f. Proses pembelajaran dapat berlangsung kapanpun dan dimanapun diperlukan.

g. Sikap positif siswa terhadap materi pembelajaran serta proses pembelajaran dapat ditingkatkan.

h. Peran guru berubah kearah yang positif.

Permainan adalah "aktivitas bermain yang didalamnya megandung unsur kompetitif dan didalamnya terdapat serangkaian aturan dalam memainkannya." Suminar (2019, hlm. 93). Belajar melalui bermain merupakan "satu teknik pengajaran dan pembelajaran yang berkesan kepada anak usia dini dengan melalui teknik ini juga akan mendatangkan kesenanagan dan kepuasan kepada mereka dalam suatu program yang hendak disampaikan" (Susanto, 2017, hlm. 97). Kegiatan bermain dengan menggunakan alat tertentu juga berperan penting bagi perkembangan anak, hal ini bertujuan untuk mengoptimalkan stimulasi perkembangan bagi anak yang dilakukan melalui penggunaan sebuah permainan. Alat permainan menurut Ardini dan Lestaningrum (2018, hlm. 37) adalah "alat yang digunakan anak ketika bermain untuk memenuhi naluri bermain anak sehingga anak dapat memperoleh pengetahuan dan pengalaman ketika bermain."

Dari uraian diatas dapat disimpulkan media permainan yaitu alat atau sarana yang digunakan untuk menyampaikan bahan pelajaran yang dikemas dalam sebuah permainan, mengandung unsur kompetitif serta memiliki aturan tertentu.

\section{Lingkup Perkembangan Bahasa Anak Usia 5 s.d. 6 Tahun}

Bahasa merupakan alat komunikasi lisan, tulisan dan isyarat yang dapat digunakan untuk mneyampaikan pesan kepada orang lain. Selain itu bahasa juga dapat digunakan sebagai sarana untuk mengekspresikan ide, mengajukan pertanyaan serta menyampaikan gagasan dan 
fikiran (Hurlock, 2007, hlm. 176; Vygotsky dalam Susanto, 2011, hlm. 73).

Lingkup perkembangan bahasa anak usia 5 samapai 6 tahun menurut Peraturan Pemerintah nomor 137 tahun 2014 tentang Standar Nasional Pendidikan Anak Usia Dini terdiri dari kemampuan memahami bahasa, kemampuan mengungkapkan bahasa dan keaksaraan.

Mengenal huruf termasuk pada salah satu lingkup perkembangan bahasa anak yaitu keaksaraan. Pengetahuan mengenai huruf menurut Lonigan dan Shanahan (dalam National Institute for Literacy, 2008) "knowing the names and sounds associated with printed letters " uraian diatas memiliki arti mengetahui nama dan suara yang terkait dengan huruf cetak.

Tarsiyem dan Hanita (2018, hlm. 40) mengemukakan manfaat mengenal huruf yaitu sebagai berikut:

a. Meningkatkan kemampuan anak dalam mengenal huruf dan menguraikan menjadi kata.

b. Meningkatkan kualitas pada pembelajaran berbahasa anak terutama dalam pengenalan huruf sehingga nantinya anak tidak mengalami kesulitan dalam mengembangkan kompetensi berbahasa khusunya pada kompetensi menulis.

c. Mengembangkan ide-ide dan karya inovatif bagi anak, menambah wawasan dan pengetahuan anak sejak dini.

\section{Pembelajaran Sains}

Fisher (dalam Mursid, 2015, hlm. 148) menyebut sains "sebagai suatu kumpulan pengetahuan yang diperoleh dengan menggunakan metode-metode yang berdasarkan pada pengamatan dengan penuh ketelitian. Kaitannya dengan program pembelajaran sains usia dini, sains dapat dikembangkan menjadi substansi mendasar, yaitu penguasaan prosesproduk-sikap sains." Pembelajaran sains bagi anak usia dini "ditujukan agar anak memiliki kemampuan memecahkan masalah, memiliki sikap ilmiah, dan mengasah kepekaan panca indera dalam bereksplorasi untuk memahami lingkungan sekitar" (Subhan, 2016, hlm. 136).

Trundle (dalam jurnal Mirawati dan Nugraha, 2017, hlm. 2) "pembelajaran sains pada pendidikan anak usia dini memberikan manfaat yang sangat besar untuk berbagai aspek perkembangan anak, sehingga para peneliti menekankan betapa pentingnya pembelajaran sains yang dimulai sejak dini." Pembelajaran sains, termasuk salah satunya pengenalan konsep kealaman bagi anak usia dini merupakan suatu upaya untuk membantu anak menemukan konsep dan proses tertentu dalam kehidupan. Pembelajaran sains bagi anak pada hakikatnya dapat dijadikan sebagai media untuk menstimulasi aspek perkembangan serta memaksimalkan potensi yang ada dalam diri anak. Pembelajaran sains bagi anak usia dini hendaknya berorientasi terhadap anak. Artinya anak akan melakukan kegiatannya sendiri dan anak pula yang akan mendapatkan hasilnya.

\section{METODE}

Metode penelitian yang digunakan yaitu pengembangan jenis EDR (Educational Design Research). EDR merupakan model penelitian yang mengembangkan solusi berbasis penelitian dalam praktik pendidikan. Model penelitian ini dianggap relevan dalam mengembangkan kualitas pembelajaran, karena mampu menjembatani perkembangan teori dan praktik pembelajaran dengan menghasilkan suatu produk yang praktis dan efektif, serta dapat mengembangkan intervensi atau tindakan yang dirancang dan didesain semaksimal mungkin hingga memunculkan perbaikan dalam bidang pendidikan.

Barab dan Squire (dalam Akker, dkk., 2006, hlm. 5) mengemukakan educational design research adalah a series of approaches, with the intent of producing new theories, artifacts, and practices that account for and potentially impact learning and teaching in naturalistic setting. pendapat diatas menjelaskan EDR sebagai serangkaian pendekatan, dengan maksud menghasilkan teori baru, artefak, dan praktik yang menjelaskan dan berpotensi berdampak pada pembelajaran dan pengajaran dalam lingkungan naturalistik. Akker, dkk. (2013, hlm. 16) mengemukakan kembali terkait tujuan dari educational design research adalah In the case of development studies, the purpose of educational design research is to develop research-based solutions for complex problems in educational practice. This type of design research is defined as the systematic analysis, design and evaluation of educational interventions with the dual aim of generating 
research-based solutions for complex problems in educational practice, and advancing our knowledge about the characteristics of these interventions and the processes of designing and developing them. Pendapat diatas memiliki arti bahwa tujuan penelitian desain pendidikan adalah mengembangkan solusi berbasis penelitian untuk masalah kompleks dalam praktik pendidikan. Jenis penelitian desain ini didefinisikan sebagai analisis sistematis, desain dan evaluasi intervensi pendidikan dengan tujuan ganda menghasilkan solusi berbasis penelitian untuk masalah kompleks dalam praktik pendidikan, dan memajukan pengetahuan kita tentang karakteristik intervensi ini dan proses perancangan dan mengembangkanya.

Jenis penelitian ini menggunakan jenis penilitian mixed method (kuantitatif dan kua kualitatif). Data kuantitatif diperoleh dari hasil studi pendahuluan dilapangan dan data kualitatif diperoleh dari hasil studi pendahuluan melalui studi literatur. Adapun tahapan-tahapan penelitian EDR yaitu sebagai berikut:

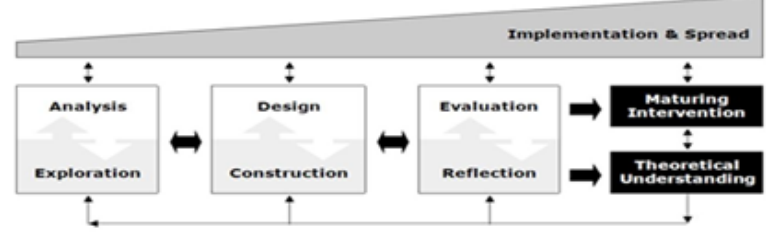

Gambar Model Generik EDR (McKenney \& Reeves, 2012)

1. Tahap Exploration and Analysis.

Pada tahap ini dilakukan analisis masalah dan mengeksplorasi masalahan melalui studi pendahuluan di lapangan dengan melakukan wawancara dan observasi terhadap fokus penelitian dan melakukan studi literatur dengan mengkaji berbagai teori seperti artikel jurnal, buku, ebook dan penelitian terdahulu yang bersifat relevan.

2. Tahap Design and Construction.

Setelah peneliti memperoleh informasi mengenai permasalahan yang menjadi fokus penelitian, selanjutnya dilakukan desain dan konstruksi dengan merancang produk yang akan dikembangkan sebagai solusi dari permasalahan tersebut.

3. Tahap Evalution and Reflection.

Tahapan evaluasi dilakukan setelah desain rancangan produk selesai dibuat dan divalidasi oleh validator ahli untuk kemudian diuji cobakan dilapangan. Namun uji coba dilapangan tidak dapat dilakukan karena adanya pandemi covid-19 (Coronavirus Disease 2019), sehingga tidak memungkinkan untuk melakukan uji coba langsung dilapangan. Oleh sebab itu tahapan penelitian dibatasi hanya sampai pada dua tahap yakni tahap analisis dan eksplorasi (analysis and exploration) serta desain dan konstruksi (design and constructio).

Teknik pengumpulan data serta instrumen yang digunakan dalam penelitian ini yaitu wawancara dengan instrumen yang digunakan pedoman wawancara, observasi dengan instrumnen yang digunakan lembar observasi, dan expert judgement dengan instrumen yang digunakan lembar validasi ahli. Secara lebih ringkas pengumpulan data dan instrumen yang digunakan disajikan dalam tabel sebagai berikut:

Tabel 1

Jenis data, teknik pengumpulan data dan Instrumen yang digunakan.

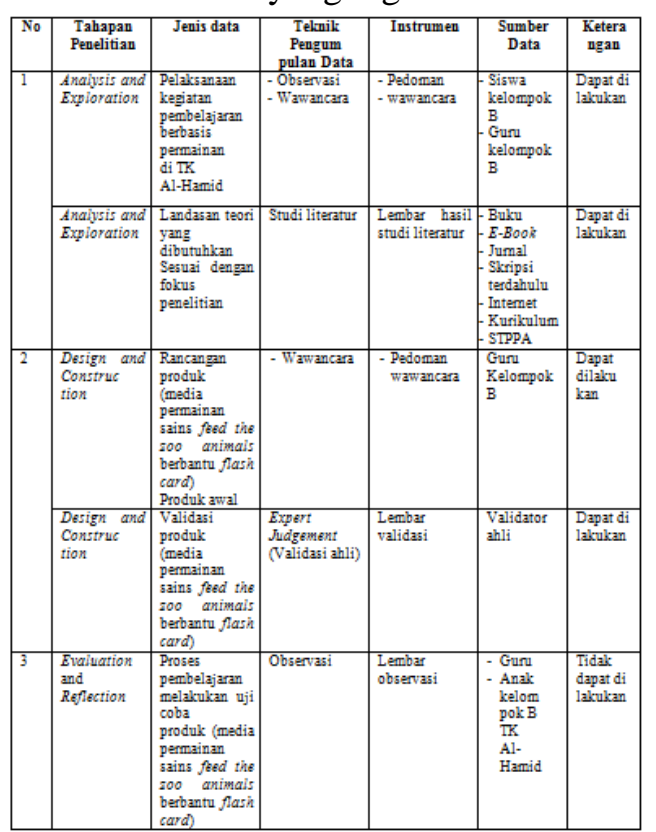

Penelitian ini dilaksanakan di TK Al-Hamid Kota Tasikmalaya. Peneliti melakukan wawancara dengan guru kelompok B1 dan melakukan observasi untuk melihat ketersediaan media pembelajaran di sekolah tersebut.

Jenis wawancara yang digunakan adalah wawancara tidak terstruktur Artinya bebas menanyakan pertanyaan-pertanyaan tanpa terikat pada pedoman wawancara . Pedoman 
wawancara yang digunakan hanya berupa garis besar permasalahan yang akan ditanyakan. Peneliti menggunakan handphone sebagai alat bantu rekam serta buku catatan pribadi untuk mencatat hal-hal penting dari percakapan dengan narasumber. Adapun secara garis besar pertanyaan yang ditanyakan terkait penggunaan media pembelajaran, disajikan dalam tabel sebagai berikut.

Tabel 2

Kisi-kisi Pedoman Wawancara

\begin{tabular}{|c|c|}
\hline \multirow[t]{9}{*}{$\begin{array}{l}\text { Penggunaan media pembelajaran } \\
\text { dalam kegiatan belajar }\end{array}$} & $\begin{array}{l}\text { Apalsah di selkolah Tbu terdapat } \\
\text { media pembelajaran? }\end{array}$ \\
\hline & $\begin{array}{l}\text { Bagaimana peran media atsu } \\
\text { permainan dalam kegiatan } \\
\text { pembelajaran? }\end{array}$ \\
\hline & $\begin{array}{l}\text { Menurut Tbu apalkah media } \\
\text { pembelajaran yang tersedia dilihat } \\
\text { dari segi jumlah sudah memadai? }\end{array}$ \\
\hline & $\begin{array}{l}\text { Apalsah media yang tersedia sudah } \\
\text { dapst memenuhi seluruh kebutuhan } \\
\text { aspek perkembangan ansk? }\end{array}$ \\
\hline & $\begin{array}{l}\text { Beraps lama waltu yang biasanya } \\
\text { digunakan anak dalam menggunakan } \\
\text { media atsu permainan? }\end{array}$ \\
\hline & $\begin{array}{l}\text { Diantara berbagai media tersebut } \\
\text { adaksh yang berkaitan dengan } \\
\text { permainan? }\end{array}$ \\
\hline & $\begin{array}{l}\text { Jika ada, spaksh permainan yang } \\
\text { digunakan tersebut ada yang } \\
\text { berkaitan dengan pembelajaran } \\
\text { sains? }\end{array}$ \\
\hline & $\begin{array}{l}\text { Apaksh pihak selkolah/guru sudah } \\
\text { berusaha untuk menyedialsan media } \\
\text { khususnya permainan sains bagi } \\
\text { anak? Jika belum apakah yang } \\
\text { menjadi kendals? }\end{array}$ \\
\hline & $\begin{array}{l}\text { Menurut Tbu yang menjadi prioritas, } \\
\text { permainan yang dapat } \\
\text { mengembangksan aspelk apaksah yang } \\
\text { dibutuhlkan pihal selkolah? }\end{array}$ \\
\hline
\end{tabular}

Selain itu juga dilakukan observasi bertujuan untuk melihat ketersediaan media pembelajaran di TK Al-Hamid khususnya kelas kelompok B. Jenis observasi yang digunaan yaitu observasi terstruktur. Instrumen yang digunakan disajikan dalam tabel dibawah ini.

Tabel 3

Instrumen Lembar Observasi Media Pembelajaran di TK Al-Hamid

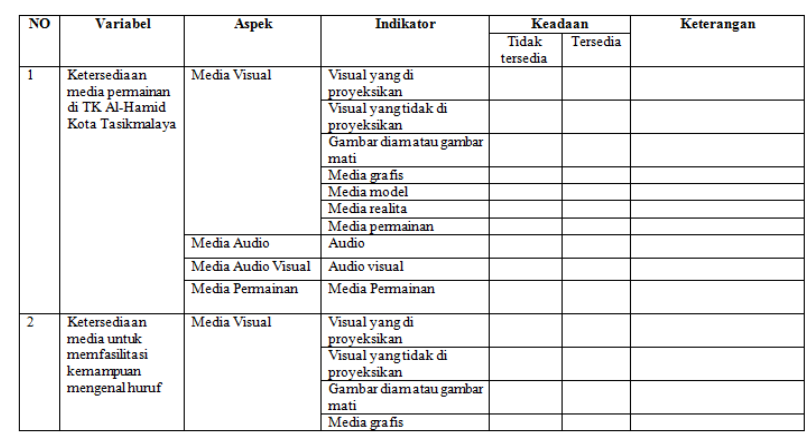

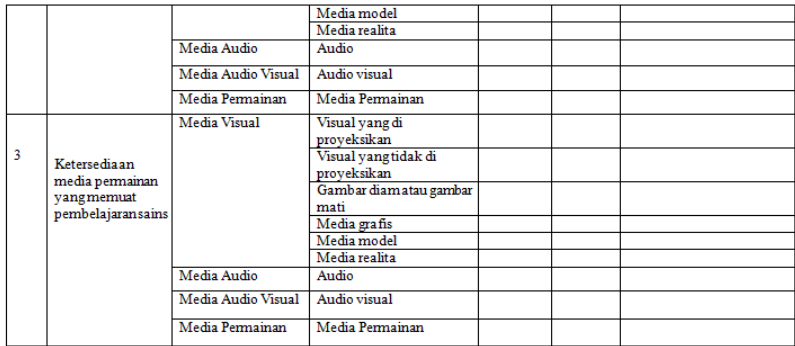

Lembar validasi ahli disajikan dalam tabel dibawah ini.

Tabel 4

Kisi-kisi Instrumen Lembar Validasi

\begin{tabular}{|c|c|c|}
\hline Validator & Aspek & Indikator \\
\hline \multirow[t]{5}{*}{ Ahli Materi } & $\begin{array}{l}\text { Keterkaitan materi dalam } \\
\text { media permainan feed the } \\
\text { zoo animals berbantu } \\
\text { flash card dengan } \\
\text { kurikulum }\end{array}$ & $\begin{array}{l}\text { Sesuai dengan ketentuan } \\
\text { dalam kurikulum } 2013\end{array}$ \\
\hline & \multirow{3}{*}{$\begin{array}{l}\text { Sains dalam permainan } \\
\text { feed the zoo animals } \\
\text { berbantu flash card }\end{array}$} & $\begin{array}{l}\text { Memfasilitasi proses } \\
\text { ilmiah }\end{array}$ \\
\hline & & $\begin{array}{l}\text { Memfasilitai produk } \\
\text { ilmiah }\end{array}$ \\
\hline & & $\begin{array}{l}\text { Memfasilitasi sikap } \\
\text { ilmiah }\end{array}$ \\
\hline & $\begin{array}{l}\text { Kemampuan mengenal } \\
\text { huruf }\end{array}$ & $\begin{array}{l}\text { Memahami keterkaitan } \\
\text { anatara simbol dan bunyi }\end{array}$ \\
\hline \multirow[t]{5}{*}{ Ahli Media } & $\begin{array}{l}\text { Keterkaitan materi dalam } \\
\text { media permainan feed the } \\
\text { zoo animals berbantu } \\
\text { flash card dengan } \\
\text { kurikulum }\end{array}$ & $\begin{array}{l}\text { Sesuai dengan ketentuan } \\
\text { dalam kurikulum } 2013\end{array}$ \\
\hline & \multirow{4}{*}{$\begin{array}{l}\text { Karakteristik mediafeed } \\
\text { the zoo animals berbantu } \\
\text { flash card }\end{array}$} & $\begin{array}{l}\text { Media yang digunakan } \\
\text { praktis dan multiguns }\end{array}$ \\
\hline & & $\begin{array}{l}\text { Bahan yang digunakan } \\
\text { aman dan tidak } \\
\text { berbahaya }\end{array}$ \\
\hline & & $\begin{array}{l}\text { Bahan yang digunakan } \\
\text { mudah didapat dan } \\
\text { bersifat tahan lama }\end{array}$ \\
\hline & & Tampilan media menarik \\
\hline & \multirow{3}{*}{$\begin{array}{l}\text { Karakteristik permainan } \\
\text { sains feed the zoo } \\
\text { animals berbantu flash } \\
\text { card }\end{array}$} & $\begin{array}{l}\text { Memenuhi syarat } \\
\text { bermain }\end{array}$ \\
\hline & & $\begin{array}{l}\text { Memiliki nilai-nilai } \\
\text { pendidikan }\end{array}$ \\
\hline & & Memiliki aturan bermain \\
\hline
\end{tabular}

\begin{tabular}{|l|l|l|}
\hline Ahli Pedagogik & $\begin{array}{l}\text { Keterkaitan materi dalam } \\
\text { media permainan feed the } \\
\text { zoo animals berbantu } \\
\text { flash card dengan } \\
\text { kurikulum }\end{array}$ & $\begin{array}{l}\text { Sesuai dengan ketentuan } \\
\text { dalam kurikulum 2013 }\end{array}$ \\
\hline & $\begin{array}{l}\text { Sains dalam permainan } \\
\text { feed the zoo animals } \\
\text { berbantu flash card }\end{array}$ & $\begin{array}{l}\text { Memfasilitasi proses } \\
\text { ilmiah }\end{array}$ \\
\cline { 3 - 3 } & $\begin{array}{l}\text { Memfasilitai produk } \\
\text { ilmiah }\end{array}$ \\
\cline { 3 - 3 } & $\begin{array}{l}\text { Memfasilitasi sikap } \\
\text { ilmiah }\end{array}$ \\
\hline & $\begin{array}{l}\text { Kemampuan mengenal } \\
\text { huruf }\end{array}$ & $\begin{array}{l}\text { Memahami keterkaitan } \\
\text { anstara simbol dan bunyi }\end{array}$ \\
\hline & $\begin{array}{l}\text { Penggunasn media dalam } \\
\text { pembelajaran }\end{array}$ & $\begin{array}{l}\text { Tampilan media } \\
\text { permainan }\end{array}$ \\
\hline
\end{tabular}

Analisis data menggunakan model Miles dan Huberman (Sugiyono, 2018). Aktivitas dalam menganalisis data, yaitu data reduction, 
data display, dan conclusion drawing/verification. Prosedur dalam penelitian ini terdiri dari tiga tahap, yaitu:

1. Reduksi data (data reduction)

Mereduksi data berarti merangkum, memilih hal-hal yang pokok, memfokuskan pada halhal yang penting, dicari tema dan polanya. Data hasil reduksi akan membeikan gambaran yang lebih jelas serta mempermudah melakukan pengumpulan data selanjutnya dan mencari bila diperlukan.

2. Penyajian data (data Display)

Adalah upaya menyajikan data untuk melihat gambaran keseluruhan atau bagian-bgaian tertentu dari peneitian. Penyajian data bisa dilakukan dalam bentuk uraian singkat, bagan, hubungan antar kategori, flowchart, dan sejenisnya

3. Kesimpulan dan verifikasi (conclusion drawing / verification.)

Tahap ini merupakan penarikan kesimpulan dan verifikasi terhadap data yang telah diperoleh. Kesimpulan dalam penelitian kualitatif adalah merupakan temuan baru yang sebelumnya belum pernah ada. Temuan dapat berupa deskripsi atau gambaran suatu objek yang sebelumnya masih remangremang sehingga setelah diteliti menjadi jelas, dapat berupa hubungan kausal atau interaktif, hipotesis, atau teori.

\section{HASIL DAN PEMBAHASAN Hasil}

Data hasil wawancara menunjukan masih kurangnya penggunaan media permainan dalam kegiatan pembelajaran sehari-hari, khususnya media permainan sains untuk memfasilitasi kemampuan mengenal huruf. Selama ini guru hanya memanfaatkan media pembelajaran yang telah tersedia sebelumnya di sekolah, media pembelajaran yang tersedia kurang dapat memfasilitasi aspek perkembangan anak. Selain itu guru merasa kesulitan dalam memilih, menggunakan, mengembangkan media pembelajaran yang sesuai dengan kebutuhan pembelajaran. Hal ini berakibat pada anak dalam proses pembelajaran yaitu anak merasa bosan dan antusiasme belajar anak menurun.

Untuk melengkapi data yang belum didapat dari proses wawancara serta mengecek kesesuaian data hasil wawancara dengan kondisi yang sebenarnya, dilakukan observasi terstruktur terkait ketersediaan media pembelajaran di sekolah tersebut. Adapun hasil observasi terkait ketersediaan media pembelajaran di TK AlHamid disajikan dalam tabel dibawah ini.

Tabel 5

Lembar Hasil Observasi Media Pembelajaran di TK Al-Hamid

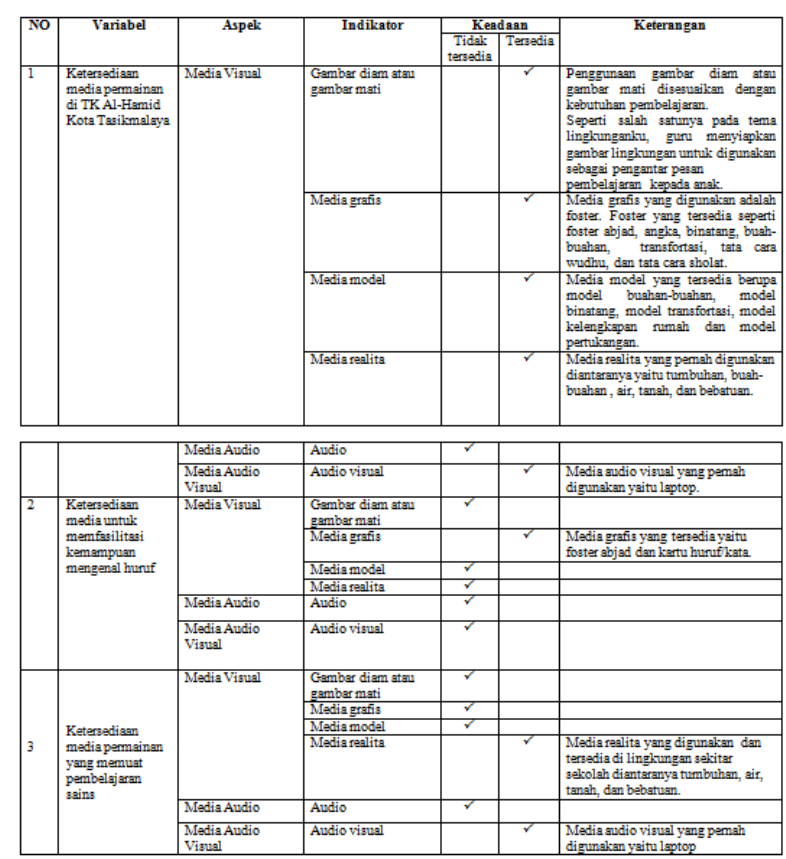

Berdasarkan data diatas menujukan bahwa penggunaan media pembelajaran khususnya dalam mengenalkan huruf kepada anak sangat minim. Dapat dilihat ketersediaan media untuk mengenalkan huruf hanya berupa foster abjad dan kartu huruf atau kata. Solusi yang pernah digunakan guru dalam mengenalkan huruf kepada anak adalah dengan menggunakan LKA (lembar kerja anak) yang berkaitan dengan huruf. selain itu belum terdapat penggunaan media permainan sains untuk memfasilitasi aspek perkembangan anak. Berdasarkan permasalahan diatas, peneliti merancang media permainan sains feed the zoo animals berbantu flash card untuk memfasilitasi kemampuan mengenal huruf anak usia dini 5 sampai dengan 6 tahun pada tema binatang.

\section{Pembahasan}

Tahapan-tahapan pada penelitian ini tidak dapat dilaksanakan secara utuh, hanya dapat dilaksanakan pada dua tahap yaitu tahap analisis dan eksplorasi (analysis and exploration) serta tahap desain dan konstruksi (design and 
construction). Sementara untuk tahap evaluasi dan refleksi (evaluation and reflection) tidak dapat dilakukan, mengingat pada tahap ini akan dilaksanakan uji coba produk hasil pengembangan. Proses uji coba yang melibatkan para pihak terkait yaitu guru dan anak tidak dapat dilakukan karena adanya pandemi covid19 (Coronavirus Disease 2019), sehingga tidak memungkinkan melakukan uji coba produk langsung di lapangan. Adapaun tahap analisis dan eksplorasi (analysis and exploration) serta tahap desain dan konstruksi (design and construction) akan dijabarkan sebagai berikut.

1. Tahap analisis dan Eksplorasi (Analysis and Exploration)

Analisis dan eksplorasi dilakukan pada saat studi pendahuluan, yaitu dengan melakukan studi literatur dan studi lapangan.

a. Studi Literatur

Pembelajaran bagi anak usia dini harus dapat mengembangkan seluruh aspek perkembangan anak. Salah satu aspek perkembangan yang harus terstimulus secara optimal adalah aspek perkembangan bahasa khususnya dalam mengenal huruf. Pengetahuan mengenal huruf menurut Lonigan dan Shanahan (dalam National Institute for Literacy, 2008) knowing the names and sounds associated with printed letters. Kutipan diatas memiliki arti bahwa dalam mengenal huruf anak dapat mengetahui nama dan suara yang terkait dengan huruf cetak. Hal ini mengindikasikan bahwa anak-anak perlu memahami kesesuaian nama, suara dan bentuk huruf. Hal tersebut juga tertuang dalam Peraturan Pemerintah nomor 137 tahun 2014 tentang Standar Nasional Pendidikan Anak Usia Dini, disebutkan bahwa perkembangan bahasa terbagi kedalam tiga lingkup perkembangan, yaitu memahami bahasa, mengungkapkan bahasa dan keaksaraan. Mengenal huruf termasuk pada kemampuan keaksaraan, didalamnya dijelaskan lebih rinci kemampuan-kemampuan mengenal huruf yang harus dikuasai anak usia 5 sampai 6 tahun yaitu diantaranya anak mampu menyebutkan simbolsimbol huruf yang dikenal dan mengelompokan gambar yang memiliki bunyi/huruf awal yang sama. Mengenal huruf merupakan salah satu hal yang harus terstimulus dengan optimal pada diri anak. Anak yang memiliki kemampuan mengenal huruf dengan baik, mereka akan dengan mudah mencerna berbagai informasi yang ia dapatkan. Lebih jauh akan membantu anak dalam kemampuan membacanya, kemampuan membaca yang dimiliki anak usia dini yaitu membaca permulaan. Ritawati (dalam Rislina dan Khan, 2015, hlm. 159) mengemukakan "membaca permulaan adalah proses memahami tulisan atau huruf yang sangat sederhana." Mengingat anak akan berinteraksi dan bersosialisasi dengan lingkungan sekitar dimana anak berada, maka kemampuan megenal huruf harus terstimulus secara optimal pada diri anak salah satunya dapat dilakukan melalui kegiatan yang menyenagkan yaitu belajar sambil bermain.

Berkaitan dengan pembelajaran bagi anak, Pendidik harus dapat menciptakan suasana belajar yang memberi kesempatan kepada anak memecahkan masalah, aktif, menemukan dan menerapkan ide-ide baru, serta mengoptimalkan keterampilan dan kemampuan yang dimiliki oleh masing-masing anak. Adapun prinsip-prinsip pembelajaran PAUD dalam Pedoman Pengelolaan Pembelajaran Pendidikan Anak Usia Dini (2015, hlm. 6) adalah sebagai berikut: 1) belajar melalui bermain, 2) berorientasi pada perkembangan anak, 3) berorientasi pada kebutuhan anak secara menyeluruh, 4) berpusat pada anak, 5) pembelajaran aktif, 6) berorientasi pada pengembangan karakter,7) berorientasi pada pengembangan kecakapan hidup, 8) lingkungan kondusif, 9) berorientasi pada pembelajaran demokratis, dan (10) menggunakan berbagai media dan sumber belajar.

Dari pendapat diatas pembelajaran bagi anak harus sesuai dengan prinsip-prinsip pembelajaran bagi anak usia dini seperti berorientasi pada perkembangan anak, berorientasi pada kebutuhan anak, berpusat pada anak serta yang paling penting adalah pembelajaran dilakukan melalui bermain. Yasin Yusuf dan Umi Auliya (2011, hlm. 17) mengemukakan beberapa manfaat belajar sambil bermain adalah "menyingkirkan keseriusan yang menghambat, menghilangkan stres dalam lingkungan belajar, mengajak siswa terlibat penuh dalam pembelajaran, meningkatkan proses belajar, membangun kreativitas diri, mencapai tujuan dengan ketidaksadaran, meraih makna belajar melalui pengalaman, dan 
memfokuskan siswa sebagai subjek belajar." Disinilah proses pembelajaran terjadi, mereka akan belajar mengambil keputusan, memilih, menentukan, mengerjakan secara tuntas, bekerja sama dengan teman serta mengalamai berbagai macam prasaan. Sementara itu Komariyah (dalam jurnal Yuliani dan Masruroh, 2014, hlm. 348) menyebutkan penambahan permainan dalam pembelajaran memiliki dua aspek positif yaitu aspek kemenarikan dan aspek mendidik. Aspek kemenarikan diperoleh dari nuansa belajar yang santai sambil bermain yang diterapkan dalam pembelajaran dan aspek mendidik diperoleh dari penerapan konsep yang dimiliki dalam permainan. Pada dasarnya kegiatan belajar melalui penggunaan sebuah permainan akan lebih optimal apabila menggunakan media sebagai alat bermain. Satrianawati (2018, hlm. 8) menjelaskan media merupakan sesuatu yang bersifat menyalurkan pesan dan dapat merangsang pikiran dan prasaan bagi penggunanya.

Berkaitan dengan proses pembelajaran, permebalajaran sains memiliki beberapa manfaat diantaranya dapat mengembangkan kemampuan berbahasa. Worms, Shadow, dan Whirlpools (dalam jurnal Mirawati dan Nugraha, 2017, hlm. 4) manfaat pembelajaran sains bagi anak yaitu dapat mengembangkan kemampuan sensor, fisik, intelektual, emosional, spiritual, dan sosial serta mengembangkan kemampuan berbahasa melalui penambahan kosakata ketika anak melakukan kegiatan menanya dan menjawab pertanyaan. Pembelajaran sains pada anak usia dini mendorong anak untuk mengeksplorasi, dan merefleksikan penemuan-penemuan baru mereka. Namun ketersediaan media yang sesuai dengan kebutuhan pembelajaran masih minim serta kegiatan pembelajaran yang dilakukan lebih berpusat pada pendidik (teacher center). Hal tersebut selaras dengan pendapat Muntomimah (2014, hlm. 74) menyatakan Di lapangan menunjukkan bahwa proses pembelajaran sains hanya mendengar ceramah dari guru atau membaca buku teks yang dilanjutkan pembahasan secara verbal. Hal itu mengakibatkan peserta didik tidak mempunyai kesempatan untuk menemukan sendiri fakta dan konsep atau memperoleh pengetahuan secara inkuiri. Pendidik dapat memberikan pembelajaran sains kepada anak usia dini dengan menggunakan pendekatan belajar sambil bermain, hal tersebut sebagaimaa dikemukakan oleh Mursid (2015, hlm. 157) pendekatan pembelajaran sains pada anak-anak hendaknya memperhatikan prinsip-prinsip yang berorientasi pada kebutuhan dan pengembangan anak serta pendekatan bermain sambil belajar.

b. Studi Lapangan

Wawancara dilakukan kepada guru kelompok B1 TK Al-Hamid Kota Tasikmalaya, dengan menggunakan jenis wawancara tidak terstuktur. Artinya peneliti bebas menanyakan pertanyaan-pertanyaan tanpa terikat pada pedoman wawancara. Pedoman wawancara yang digunakan hanya berupa garis besar permasalahan yang akan ditanyakan. Peneliti menggunakan alat bantu berupa handphone sebagai alat bantu rekam serta buku catatan pribadi untuk mencatat hal-hal penting dari percakapan dengan narasumber.

Untuk melengkapi data yang belum didapat dari proses wawancara serta mengecek kesesuaian data hasil wawancara dengan kondisi yang sebenarnya, dilakukan observasi terstruktur terkait ketersediaan media pembelajaran di sekolah tersebut khususnya di kelas kelompok B.

2. Desain dan konstruksi (Design and Construction)

a. Perancangan Desain Produk

Dalam merancang produk yang dikembangkan terlebih dahulu dilakukan analisis terhadap program oengembangan anak usia 5 sampai dengan 6 tahunyang dihungkan dengan KI (kompetensi inti), KD (kompetensi dasar), indikator, model pembelajaran, tujuan pembelajaran serta penggunaan materi dalam media permainan sains sebagai produk yang dikembangkan. Untuk program pengembangan yang dapat dioptimalkan terdapat dalam kurikulum PAUD 2013 yaitu pengembangan bahasa, kognitif dan sosial emosional. Kompetensi inti yang digunakan terdiri dari kompetensi inti 2 yaitu berkaitan dengan sosial, kompetensi inti 3 berkaitan dengan pengetahuan dan kompetensi inti 4 berkaitan dengan keterampilan. Sedangkan untuk kompetensi dasar terdiri dari kopetensi dasar 2.2, 2.7, 2.12, $3.3-4.3, \quad 3.8-4.8, \quad 3.12-4.12,3.15-4.15$ dan indikator pecapaian terdiri dari hal-hal yang berhubungan dengan perkembangan bahasa, 
kognitif dan sosial anak usia dini. Model pembelajaran yang digunakan yaitu model pembelajaran kelompok, tujuan pembelajaran yakni dapat memfasilitasi kemampuan mengenal huruf bagi anak yang dipadukan melalui penanaman konsep sains mengenal binatang dan jenis makannya. Materi pembelajaran memuat tentang pembelajaran sains bagi anak usia dini yang memenuhi tiga dimensi penting yaitu proses, produk dan sikap. Media pembelajaran yang digunakan berupa hasil pengembangan yaitu media permainan sains feed the zoo animas berbantu flash card.

b. Dasar Pengembangan Produk

Alat dan bahan yang digunakan dalam pembuatan media permainan sains feed the zoo animals, disajikan dalam tabel dibawah ini.

\section{Tabel 6}

Alat dan Bahan Media Permainan Sains Feed

The Zoo Animals Berbantu Flash Card
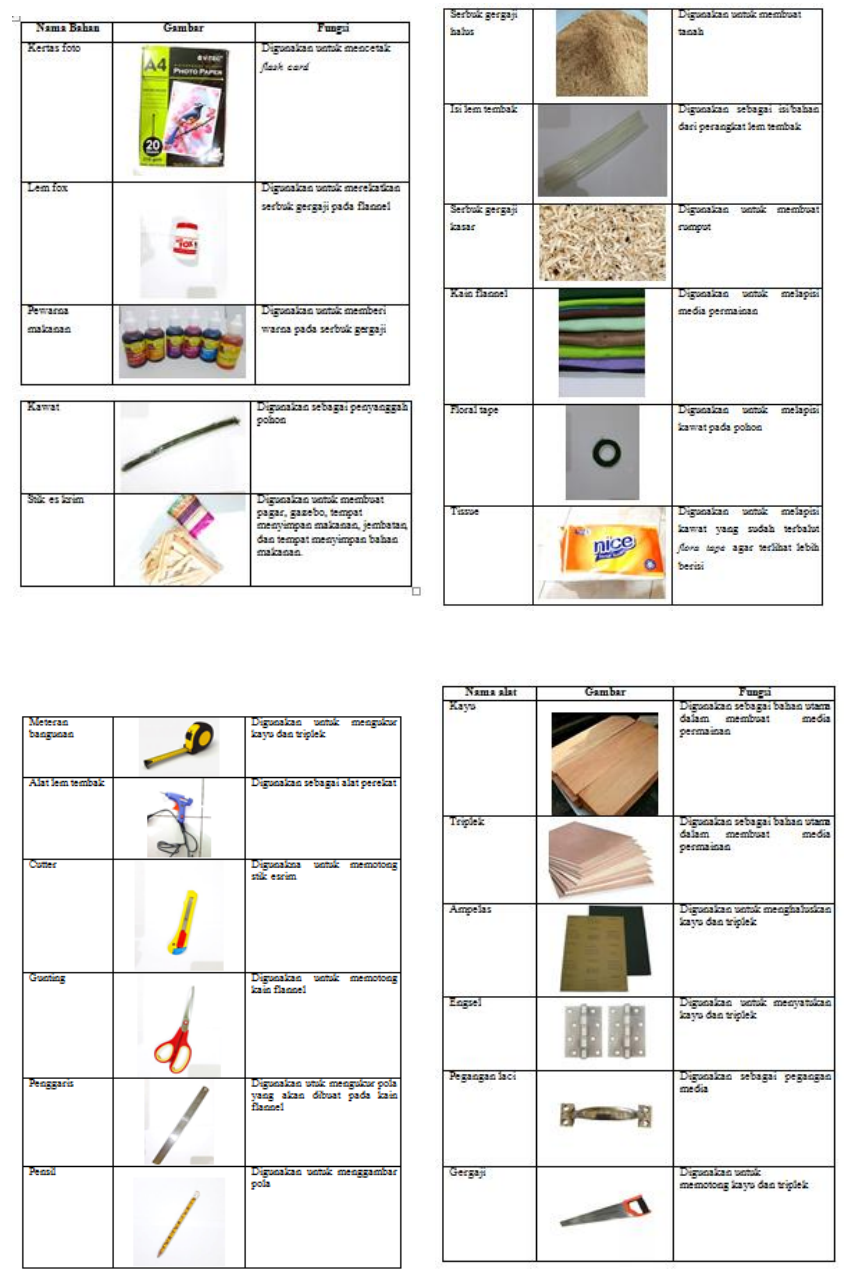

Adapun langkah-langkah pembuatan media permainan sains sains feed the zoo animas berbantu flash card. Adalah sebagai berikut:

1) Menyediakan alat dan bahan yang akan digunakan seperti; kayu, triplek, engsel, pegangan pintu, gergaji, meteran bangunan, ampelas, kain flannel, lem dan tembakannya, gunting, pensil, dan penggaris.

2) Potonglah kayu dan triplek dengan ukuran sebagai berikut:

a) Kayu dengan panjang $50 \mathrm{~cm}$ dan lebar $50 \mathrm{~cm}$ sebanyak dua buah, digunakan untuk penutup dan alas media permainan.

b) Kayu dengan panjang $50 \mathrm{~cm}$ dan lebar $7 \mathrm{~cm}$ sebanyak satu buah, digunakan sebagai kaki penyanggah media permainan.

c) Kayu dengan panjang $50 \mathrm{~cm}$ dan lebar $12 \mathrm{~cm}$ sebanyak tiga buah serta kayu dengan panjang $50 \mathrm{~cm}$ dan lebar $7 \mathrm{~cm}$ sebanyak satu buah, digunakan sebagai dinding media permainan.

d) Tripek dengan panjang $43 \mathrm{~cm}$, lebar $43 \mathrm{~cm}$ dan tinggi setiap sisinya $6 \mathrm{~cm}$ (sebanyak tiga buah) sebagai bahan untuk membuat laci yang akan disimpan dibagian dalam media permainan.

e) Triplek dengan panjang $50 \mathrm{~cm}$ dan lebar $50 \mathrm{~cm}$, digunakan sebagai penyekat antara laci dengan lahan yang akan digunakan untuk permainan.

f) Triplek dengan panjang $50 \mathrm{~cm}$ dan lebar $5 \mathrm{~cm}$, digunakan untuk menghubungkan kayu yang menjadi penutup dan alas media permainna.

3) Langkah selanjutnya adalah merekatkan kayu berukuran $50 \mathrm{~cm} \times 12 \mathrm{~cm}$ pada ketiga sisi alas media permainan dan satu sisi lagi berukuran $50 \mathrm{~cm} \times 7 \mathrm{~cm}$ dengan rapih.

4) Selanjutnya buatlah pola berukuran $43 \mathrm{~cm} x$ $5 \mathrm{~cm}$ dengan menggunakan pensil pada salah satu bagian sisi (bagian depan), kemudian potong pola tersebut. Ini digunakan untuk menyimpan laci penyimpanan.

5) Setelah itu sekat bagian dalam media permainan dengan menggunakan triplek berukuran $50 \mathrm{~cm} \times 50 \mathrm{~cm}$, sehingga antara laci 
penyimpanan dengan lahan untuk bermain menjadi terpisah.

6) Kemudian rekatkan triplek berukuran $42 \mathrm{~cm} \mathrm{x}$ $42 \mathrm{~cm}$ dengan tinggi disetiap sisinya $6 \mathrm{~cm}$ dengan rapih. Kemudian diluar salah satu sisi (bagian depan) rekatkan pegangan pintu yang telah disiapkan sebelumnya, hal ini bertujuan agar memudahkan pada saat akan membuka laci penyimpanan. Setelah semuanya selesai, masukan laci tersebut kedalam media permainan.

7) Langkah selanjutnya sambungkan sekat tersebut dengan bagian penutup media permainan dengan cara simpan triplek berukuran $50 \mathrm{~cm} \times 5 \mathrm{~cm}$ ditengah-tengah antara sekat dengan bagian tutup media permainan. Selanjutnya Pasang engsel dibagian atas antara kayu dan triplek tersebut agar lebih kuat.

8) Dibagian luar penutup media permainan, rekatkan kayu berukuran $50 \mathrm{~cm}$ x $7 \mathrm{~cm}$ yang berfungsi sebagai kaki penyanggah. Sehingga ketika media permainan tersebut dibuka, antara lahan yang akan digunakan untuk permainan dengan bagian penutup media akan sejajar.

9) Setelah itu lapisi semua bagian luar dari media permainan tersebut dengan menggunakan kain flannel. Hal ini agar media permainan yang digunakan lebih aman, nyaman serta menarik bagi anak.

10) Terakhir beri nama pada bagian depan media permainan tesebut dengan terlebih dahulu mempola huruf-huruf yang diperlukan dengan menggunakan penil pada kain flannel. Kemudian temple potonganpotongan kain flannel tersebut menggunakan lem dan tembakannya.

c. Merancang Prototype Awal Desain Media Permainan Sains Feed The Zoo Animals Berbantu Flash Card

Prototype yang dimaksud adalah rancangan awal media permainan sains feed the zoo animals berbantu flash card untuk memfasilitasi kemampuan mengenal huruf. Rancangan awal dari media tersebut dibuat setelah melakukan analisis terhadap program pengembangan, kompetensi inti, kompetensi dasar, indikator pencapaain, model pembelajaran, tujuan pembelajaran dan materi. Adapun rancangan awal media permainan sains feed the zoo animals berbantu flash card terdiri dari desain awal produk yang akan disajikan dalam tabel dibawah ini.

Tabel 7

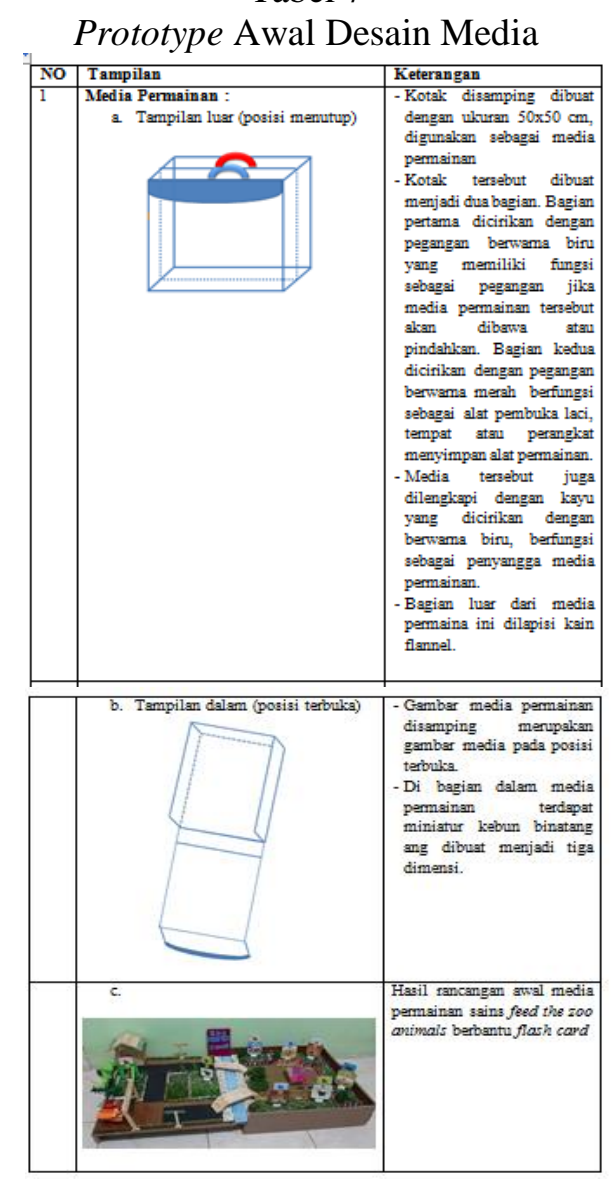

d. Validasi Produk Media Permainan sains Feed The Zoo Animals Berbantu Flash Card

Pemilihan validator disesuaikan dengan bidang keahliannya, adapun ahli yang melakukan penilaian pada produk yang dikembangkan yaitu ahli materi, ahli media pembelajaran, dan ahli pedagogik. Validator pertama sebagai ahli materi, melakukan penilaian terhadap materi yang terkandung pada media permainan. Validator kedua sebagai ahli media melakukan penilaian terhadap desain media permainan yang dibuat. Validator ketiga sebagai ahli pedagogik, melakukan penilaian terhadap kepraktisan penggunaan produk dilapangan.

Terdapat beberapa saran yang diberikan oleh masing-masing ahli. Saran tersebut antara lain sebagai berikut: 
1) Memastikan komponen-komponen yang terdapat dalam media permainan kuat sehingga dapat digunakan berulang kali.

2) Dalam manual book ditambahkan poin yang membahas resiko bermain beserta cara menanggulanginya.

3) Memvariasikan atau menambah jenis makanan yang akan digunakan dalam permainan.

4) Materi sains yang semula hanya mengenalkan binatang berdasarkan kelompok karnivora dan herbivora dapat dioptimalkan dengan mengenalkan binatang kelompok omnivora.

5) Gambar binatang yang terdapat dalam flash card merupakan binatang yang dikenal anak atau berada disekitar anak.

Menurut ahli materi, ahli media pembelajaran dan ahli pedagogik, media permainan sains feed the zoo animals berbantu flash card layak untuk selanjutnya digunakan dalam proses pembelajaran bagi pendidikan anak usia dini sesuai dengan saran dan rekomendasi dari validator.

\section{KESIMPULAN}

Dasar kebutuhan penggunaan media permainan sains dalam proses pembelajaran perlu dikembangkan, karena masih minimnya penggunaan sebuah permainan khususnya permainan sains dalam kegiatan pembelajaran. Berdasarkan analisis pada studi pendahuluan, disimpulkan bahwa belum adanya penggunaan permainan sains untuk memfasilitasi kemampuan mengenal huruf bagi anak usia 5 sampai 6 tahun. Media pembelajaran yang selama ini digunakan untuk mengenalkan huruf kepada anak tidak secara khusus dipilih untuk memfasilitasi kemampuan mengenal huruf dan pembelajaran sains bagi anak. Sebagai salah satu alternatif pemecahan masalah berdasarkan hasil analisis dan eksplorasi masalah dilapangan, maka dilakukan pengembangan media pemainan sains feed the zoo animals berbantu flash card .

Analisis dilakukan terhadap program pengembangan anak usia 5 sampai dengan 6 tahun yang dihubungkan dengan KI (kompetensi inti), KD (kompetensi dasar), indikator, model pembelajaran, tujuan pembelajaran serta penggunaan materi dalam media permainan sains tersebut. Setelah rancangan produk selesai dibuat, selanjutnya dilakukan penilaian atau validasi oleh validator ahli sesuai dengan bidang keahliannya. Validator ahli yang dimaksud yaitu terdiri dari ahli materi, ahli media pembelajaran dan ahli pedagogik. Kemudian dilakukan revisi produk dengan memperhatikan saran dan rekomendasi dari para ahli sebagai dasar untuk melakukan perbaikan-perbaikan, agar produk yang dihasilkan layak digunakan di lapangan dalam proses pembelajaran. Dari hasil validasi disimpulkan bahwa media permainan sains feed the zoo animals berbantu flash card layak untuk selanjutnya digunakan dalam proses pembelajaran di PAUD.

\section{SARAN}

Hasil pengembangan media permainan sains feed the zoo animals berbantu flash card diharapkan menjadi bahan masukan dalam penggunaan media permainan sains untuk memfasilitasi perkembangan anak. Bagi lembaga pendidikan anak usia dini khususnya ditempat penelitian, dapat menambah wacana tentang anternatif ketersediaan media permainan sains yang dapat digunakan untuk memfasilitasi kemampuan mengenal huruf. Selain itu bagi guru media permainan sains feed the zoo animals berbantu flash card dapat menjadi bahan acuan dalam menciptakan media permainan sains yang sesuai dengan kebutuhan pembelajaran.

\section{DAFTAR PUSTAKA}

Aba, L. (2019). Flashcards as A Media in Teaching English Vocabulary. Jurnal: Bahasa (e-journal), 5(2), 172. doi: http:// journal.iaingorontalo.ac.id/index.php/al.

Akker, D.V.J., dkk. (2006). Educational Design Research. New York : Routledge.

Akker. D. V. J., dkk. (2013). Educational Design Research. Enschede: Netherland Institute for Curriculum Development (SLO).

Ardini, P.P \& Lestariningrum, A. (2018). Bermain \& Permainan Anak Usia Dini. Cetakan pertama. Nganjuk: CV. Adjie Media Nusantara.

Asmarita, W. (2019). Pengaruh Penerapan Metode Permainan Sains Penggabungan Warna Terhadap Perkembangan Kognitif Anak Kelompok B Di Taman Kanakkanak Bintang Mulia Rimbo Panjang 
Kecamatan Tambang. (Skripsi). Fakultas Tarbiyah Dan Keguruan. Universitas Islam Negeri Sultan Syarif Kasim Riau. Pekanbaru.

Desmita. (2017). Psikologi Perkembangan Peserta Didik. Bandung: PT Remaja Rosdakarya.

Hurlock, E.B. (2007). Perkembangan Anak. (Edisi Keenam). Jakarta: Erlangga.

Hasnida. (2014). Media Pembelajaran Kreatif Mendukung Pembelajaran pada Anak usia Dini. Jakarta: Luxima.

Kementrian Pendidikan dan Kebudayaan. (2015). Pengelolaan Pembelajaran Pendidikan Anak Usia Dini. Jakarta: Kemendikbud.

Mirawati dan Nugraha, R. (2017). Meningkatkan Keterampilan Proses Sains Anak Usia Dini melalui Aktivitas Berkebun. Early Childhood: Jurnal Pendidikan, 1(1), 2-7.

Moomaw, S. (2013). Teaching STEM in The Early Years. St Paul, MN, United States : Redleaf Press.

Muntomimah, Siti. (2014). Peningkatan Kemampuan Sains melalui Sentra Bahan Alm. Conaplin Journal:Jurnal Pendidikan Usia Dini, 8, doi: http://pps.unj.ac.id/journal/jpaud/article/ view/58.pdf.

Mursid. (2015). Belajar dan Pembelajaran PAUD. Bandung: PT Remaja Rosdakarya.

National Institute For Literacy. (2008). Developing Early Literacy: Report of the National Early Literacy Panel. Washington, DC: National Institute for Literacy.

Peraturan Menteri Pendidikan dan Kebudayaan Republik Indonesia Nomor 137 Tahun 2014 tentang Standar Nasional Pendidikan Anak Usia Dini.

Rasyid, I \& Rohani. (2018). Manfaat Media Dalam Pembelajaran. 7(2), 93.

Rislina, S \& Khan, R. (2015). Mengenalkan Huruf Melalui Loncat Abjad pada Anak Usia 4-5 Tahun. 02(02), 159.

Santrock, J. (2007). Perkembangan Anak. (Edisi kesebelas). Jakarta: Erlangga.

Satrianawati. (2018). Media dan Sumber Belajar. Cetakan pertama. Yogyakarta: Deepublish.
Sudono, A. (2010). Sumber Belajar dan Alat Permainan untuk Pendidikan Usia Dini. Cetakan keenam. Jakarta: PT Gramedia.

Sugiyono. (2018). Metode Penelitian Kuantitatif, Kualitatif dan $R \& D$. Bandung: Alfabeta.

Suminar, D.R. (2019). Psikologi Bermain. Surabaya: Airlangga University Press.

Susanto. (2017). Pendidikan Anak Usia Dini. (Cetakan pertama). Jakarta: PT Bumi Aksara.

Susanto, A. (2011). Perkembangan Anak Usia Dini. (Edisi pertama). Jakarta: Kencana.

Susilana, R. \& Riyana, C. (2018). Media Pembelajaran Hakikat, Pengembangan. Pemanfaatan dan Penilaian. Bandung: Wacana Prima.

Suyadi. (2015). Teori Pembelajaran Anak Usia Dini. Bandung: PT Remaja Rosdakarya.

Tedjasaputra, M.S. (2001). Bermain, Mainan dan Permainan untuk Pendidikan Usia Dini. Jakarta: PT Grasindo.

Yusuf, Y \& Auliya, U. (2011). Sirkuit Pintar Melejitkan Kemampuan Matematika dan Bahasa Inggris dengan Metode Ular Tangga. Jakarta : Visimedia.

Yuliani, E.S \& Masruroh, U. (2014). Pengembangan Media Permainan Penemuan Harta Karun Finding Treasure Pada Sub Pokok Bahasan Respirasi sel. 3(2), 348. http://ejournal.unesa.ac.id/index.php/bioe du.

Zaman, B \& Eliyawati, C. (2010). Media Pembelajaran Anak Usia Dini. Universitas Pendidikan Indonesia. 